\title{
China's Energy Import Market Structure and Its Effects on Energy Security
}

\author{
Guicai Dong
}

\begin{abstract}
School of International Trade and Economic,Anhui University of Finance and Economic,Caoshan Road NO.962,Bengbu City,Anhui Province,China
\end{abstract}

dongguicai@163.com

\begin{abstract}
Keywords: Energy import;Energy security;Energy dependence
Abstract. Energy is an important strategic resource of a country, and its stable supply is of great importance to the security of a country, especially economic security. Due to diversification, stability is the basic view of ecology. Based on the market concentration index and diversity index in industrial economics and information economics, this paper analyzed the market structure of China's major energy import, and then calculated the dependence coefficient of China on the main sources of energy import. The results showed that China's import market structure of oil, coal and natural gas is highly concentrated, and different sources of energy import vary in the price. If the export space of international energy market can be fully used, China's energy security and its status in the trade negotiations with some energy export countries can be further improved to reduce energy import prices and improve energy trade terms.
\end{abstract}

\section{Introduction}

Energy is the most basic driving force for the development and economic growth of the whole world, which is the basis for the survival of mankind. On the whole, China's energy reserves are rich, but the structural contradictions are more prominent, mainly reflected in more coal reserves but fewer oil and natural gas reserves. Although the reserves of coal are rich, they are mostly distributed in Shanxi, Inner Mongolia, Guizhou and other inland provinces, while the large consumers are mainly in the southeast coastal provinces and cities, and as a result of high inland transport costs, coastal areas seek for import coal. With the rapid economic development, China's oil imports are rising year after year, which reached about 22.7 billion US dollars in 2012, 15 times as 15 billion US dollars in 2000, and of course there are causes from rising oil prices. In addition, China's natural gas and liquefied petroleum gas imports are also increasing. With the growth of imports, China's energy import dependence is rising, but the high concentration of China's energy import sources is not changed. The impact of this over-centralized pattern of imports on China's energy security is worth studying.

\section{Structure analysis of China's energy import market}

This paper analyzed only the main import markets and the structures of three major mineral energy sources, crude oil, coal and natural gas, as well as the changes in different energy import market structures, and provided a reference for the development of diversified import trade policy.

Oil import market structure. All countries in the development of energy security policy first considerate oil supply security. The rapid growth of China's economy has led to an increasing demand for oil, but the production and reserves of oil in China cannot meet this growing need, therefore it has to depend on external supply. In 1993, China became a net importer of oil, and the external dependence of oil continued to increase. At present, China has become the world's first largest oil consumer, whose dependence on imports of crude oil has reached about 50\%. China's imports of oil in 2015 reached 239 million tons, 135.3 billion US dollars. As can be seen from China's crude oil import market structure and import prices listed in Table 1: First, China's oil import market is highly concentrated, the imports from the top five countries over the years have reached about $60 \%$ of China's total oil imports, and the highest concentration of import markets, 65\%, appeared in 2009 and 2011. Second, China's oil 
imports are mainly targeted at Saudi Arabia, Angola and Iran, indicating that their domestic economic and political conditions have an important impact on China's oil security. Third, China's imports from Russia are rising, indicating that Russia is more and more important in the future oil supply to China. Fourth, China's oil imports from Iran present a downward trend, from 15\% in 2009 to $8 \%$ in 2015, but Iran is still one of China's five sources of oil imports, so the impact of Iran's nuclear crisis on China's oil security cannot be ignored. Regardless of the quality of oil, China's oil imports from Iran are generally cheaper than other countries, which also reflect the dependence of Iran's oil exports on China's oil market under the pressure of international community.

Table1 China's oil import market stucture and price

\begin{tabular}{|c|c|c|c|c|c|c|c|}
\hline \multirow{3}{*}{2009} & country & Saudi Arabia & Angola & Iran & Russia & Oman & total/average \\
\hline & share & 17 & 16 & 12 & 11 & 9 & 65 \\
\hline & price & 462 & 466 & 464 & 470 & 462 & 457 \\
\hline \multirow{3}{*}{2010} & country & Saudi Arabia & Angola & Iran & Russia & Oman & total/average \\
\hline & share & 16 & 16 & 13 & 9 & 8 & 62 \\
\hline & price & 498 & 515 & 509 & 497 & 480 & 489 \\
\hline \multirow{3}{*}{2011} & country & Saudi Arabia & Angola & Iran & Oman & Russia & total/average \\
\hline & share & 20 & 17 & 12 & 9 & 7 & 65 \\
\hline & price & 709 & 747 & 739 & 771 & 737 & 723 \\
\hline \multirow{3}{*}{2012} & country & Saudi Arabia & Angola & Iran & Russia & Oman & total/average \\
\hline & share & 21 & 16 & 11 & 8 & 6 & 62 \\
\hline & price & 452 & 453 & 423 & 432 & 425 & 438 \\
\hline \multirow{3}{*}{2013} & country & Saudi Arabia & Angola & Iran & Oman & Russia & total/average \\
\hline & share & 19 & 16 & 9 & 7 & 6 & 57 \\
\hline & price & 572 & 577 & 566 & 573 & 582 & 565 \\
\hline \multirow{3}{*}{2014} & country & Saudi Arabia & Angola & Iran & Russia & Oman & total/average \\
\hline & share & 20 & 13 & 11 & 8 & 7 & 59 \\
\hline & price & 776 & 797 & 786 & 828 & 761 & 775 \\
\hline \multirow{3}{*}{2015} & country & Saudi Arabia & Angola & Russia & Iran & Oman & total/average \\
\hline & share & 20 & 15 & 9 & 8 & 7 & 59 \\
\hline & price & 819 & 831 & 842 & 812 & 808 & 815 \\
\hline
\end{tabular}

Data source:Uncomtrade database( https://comtrade.un.org/db/).

China's coal import market structure and import prices. Although the reserves of coal in China are rich, they are mostly distributed in Shanxi, Inner Mongolia, Guizhou and other inland provinces, while the large consumers are mainly in the southeast coastal provinces and cities, and as a result of high inland transport costs, coastal areas seek for import coal. In 2002, China imported a total of 328 million US dollars of coal (10.81 million tons), which increased to 16.9 billion US dollars (164.57 million tons) in 2015. During this period, import prices were also rising, and the average import price in 2002 was 30 US dollars per ton, which rose to 103 US dollars per ton in 2015 by more than 2 times. Although its coal imports continued to grow, China had been a net coal exporter until 2008, but in 2009, China became a net coal importer for the first time. China's coal import market structure and prices are listed in Table 2. Compared with oil, China's coal import market is more concentrated, mainly from Australia, Vietnam, Indonesia, Canada, Russia and Mongolia that play an increasingly important role in China's coal imports. Compared with the import price of oil, different coal import sources vary in the import price. For example, the import price from Australia in 2009 was 76 US dollars per ton, while that from Vietnam was only 32 US dollars per ton, 2 times lower. 
Table 2 China's coal import market stucture and price [Unit : \% , US. Dallars/ton]

\begin{tabular}{|c|c|c|c|c|c|c|c|}
\hline \multirow{3}{*}{2009} & country & Viet Nam & Australia & Indonisia & North Korea & Russia & total/average \\
\hline & share & 40 & 32 & 14 & 6 & 3 & 95 \\
\hline & price & 32 & 76 & 45 & 39 & 54 & 42 \\
\hline \multirow{3}{*}{2010} & country & Viet Nam & Indonisia & Australia & North Korea & Mongolia & total/average \\
\hline & share & 38 & 31 & 17 & 7 & 4 & 97 \\
\hline & price & 38 & 53 & 91 & 43 & 31 & 47 \\
\hline \multirow{3}{*}{2011} & country & Viet Nam & Indonisia & Australia & Mongolia & North Korea & total/average \\
\hline & share & 32 & 27 & 15 & 7 & 6 & 87 \\
\hline & price & 67 & 86 & 150 & 60 & 80 & 87 \\
\hline \multirow{3}{*}{2012} & country & Australia & Indonisia & Viet Nam & Russia & Canada & total/average \\
\hline & share & 46 & 19 & 12 & 10 & 5 & 92 \\
\hline & price & 111 & 67 & 54 & 87 & 132 & 84 \\
\hline \multirow{3}{*}{2013} & country & Australia & Indonisia & Russia & Viet Nam & Mongolia & total/average \\
\hline & share & 32 & 26 & 9 & 8 & 6 & 81 \\
\hline & price & 147 & 79 & 130 & 73 & 61 & 103 \\
\hline \multirow{3}{*}{2014} & country & Indonisia & Australia & Viet Nam & Mongolia & Russia & total/average \\
\hline & share & 30 & 25 & 9 & 8 & 8 & 79 \\
\hline & price & 98 & 158 & 83 & 79 & 149 & 114 \\
\hline \multirow{3}{*}{2015} & country & Australia & Indonisia & Russia & Mongolia & South Africa & total/average \\
\hline & share & 31 & 24 & 9 & 7 & 6 & 77 \\
\hline & price & 130 & 91 & 119 & 78 & 110 & 108 \\
\hline
\end{tabular}

Data source:Uncomtrade database( https://comtrade.un.org/db/).

China's natural gas import market structure and import prices. With the development of the world economy, the impact of the oil crisis and the increasing pollution caused by coal and oil gradually changed the energy structure, and the consumption and imports of natural gas in China also increased sharply. In 2000, China imported 1.54 billion US dollars of natural gas, 4.8 billion cubic meters, which increased to 20.2 billion US dollars, 34 billion cubic meters, in 2015. As can be seen from China's natural gas import market structure and prices listed in Table 3, China's natural gas imports are mainly from Saudi Arabia, Australia and the United Arab Emirates, Thailand, Iran and Malaysia occupy an important position in China's natural gas imports, and in recent years Qatar and Turkmenistan become important sources of China's natural gas imports. According to the analysis in this article, the difference between natural gas prices from different sources of imports is the largest. In 2013, for example, the average import price of natural gas from Qatar was 683 US dollars per cubic, while it was 227 US dollars per cubic from Australia, 3 times more. It is difficult to think that the price difference is caused by the quality of natural gas, but it should be said that the quality difference of natural gas is not as big as that of coal. 
Table 3 China's nature gas import market structure and price [Unit:\%,US. Dallars $/ \mathrm{m}^{3}$ ]

\begin{tabular}{|c|c|c|c|c|c|c|c|}
\hline \multirow{3}{*}{2009} & country & Australia & UAE & Saudi Arabia & Iran & Kuwait & total/average \\
\hline & share & 22 & 17 & 17 & 16 & 12 & 84 \\
\hline & price & 395 & 536 & 545 & 532 & 543 & 500 \\
\hline \multirow{3}{*}{2010} & country & Australia & Iran & Saudi Arabia & Kuwait & UAE & total/average \\
\hline & share & 32 & 13 & 12 & 12 & 12 & 80 \\
\hline & price & 289 & 603 & 599 & 598 & 603 & 443 \\
\hline \multirow{3}{*}{2011} & country & Australia & UAE & Kuwait & Saudi Arabia & Iran & total/average \\
\hline & share & 18 & 14 & 14 & 12 & 11 & 69 \\
\hline & price & 184 & 778 & 808 & 718 & 741 & 488 \\
\hline \multirow{3}{*}{2012} & country & Australia & Qatar & Iran & Malaysia & UAE & total/average \\
\hline & share & 23 & 17 & 17 & 9 & 9 & 74 \\
\hline & price & 201 & 527 & 489 & 367 & 478 & 348 \\
\hline \multirow{3}{*}{2013} & country & Qatar & Turkmenistan & Australia & Iran & Malaysia & total/average \\
\hline & share & 20 & 16 & 15 & 10 & 7 & 68 \\
\hline & price & 683 & 383 & 227 & 714 & 362 & 419 \\
\hline \multirow{3}{*}{2014} & country & Turkmenistan & Qatar & Australia & Malaysia & Iran & total/average \\
\hline & share & 35 & 21 & 6 & 5 & 4 & 71 \\
\hline & price & 449 & 873 & 202 & 455 & 838 & 515 \\
\hline \multirow{3}{*}{2015} & country & Turkmenistan & Qatar & Australia & Malaysia & UAE & total/average \\
\hline & share & 42 & 27 & 4 & 4 & 4 & 81 \\
\hline & price & 543 & 962 & 228 & 441 & 936 & 593 \\
\hline
\end{tabular}

Data source:Uncomtrade database( https://comtrade.un.org/db/).

\section{Diversity index analysis of China's energy import market}

Energy is an important strategic resource of a country, and its stable supply is of great importance to the security of a country, especially economic security. Due to diversification, stability is the basic view of ecology. It is generally believed that if a country's energy comes mainly from international markets, the country should pursue diversified sources of imports to avoid risk concentration and improve its own energy security. In fact, exporting countries are also pursuing diversification of export markets in order to avoid dependence on a single market. The concept of market concentration was used above to analyze the share and accumulation of China's top five sources in its energy imports, but the market concentration only used major market information without considering the structural change of other markets. To compensate for this flaw, the diversity index was used to further analyze the change trend China's energy import market structure. The diversity index was calculated by the following formula ${ }^{[1]}$ :

$$
D=-\sum_{i=1}^{n} D_{i} \operatorname{Ln} D_{i}
$$

$D$ represents the diversity index, and $D_{i}$ represents the share $\mathrm{i}$ in China's total energy imports. $\mathrm{n}$ is the total number of sources of China's energy imports. The value range of $\mathrm{D}$ is $\mathrm{D}>0$. When China only imports energy from one country, $\mathrm{D}_{\mathrm{i}}=1$, then $\mathrm{D}=0$. As $\mathrm{D}$ becomes larger, the share of China's imports from all energy sources tends to the average with the gap narrowed and the import market structure optimized; As D becomes smaller, China's energy sources focus on fewer countries, whose share in China's imports increases, with a widening gap from other countries with smaller share, and China's energy import market structure tends to deteriorate.

As can be seen from the diversity index of China's energy import market listed in Table 4, China's oil import market structure changed little from 2003 to 2015, and the diversity index rose slightly, indicating that during this period China's oil import market structure improved slightly, and the diversity of coal import markets increased. Natural gas import market structure experienced a process 
from centralization to decentralization and the import market diversity index in 2015 decreased slightly in comparison with that in 2003, indicating that China's natural gas import market structure was in deterioration.

Table 4 The diversity index of China's energy import market

\begin{tabular}{c|c|c|c|c|c|c|c|c|c|c|c|c|c}
\hline year & 2003 & 2004 & 2005 & 2006 & 2007 & 2008 & 2009 & 2010 & 2011 & 2012 & 2013 & 2014 & 2015 \\
\hline oil & 2.74 & 2.74 & 2.7 & 2.74 & 2.83 & 2.72 & 2.72 & 2.79 & 2.68 & 2.74 & 2.79 & 2.8 & 2.81 \\
\hline coal & 1.16 & 1.58 & 1.53 & 1.44 & 1.57 & 1.62 & 1.49 & 1.5 & 1.81 & 1.61 & 1.95 & 2.01 & 2.05 \\
\hline gas & 2.55 & 2.65 & 2.6 & 2.56 & 2.17 & 2.16 & 2.13 & 2.14 & 2.36 & 2.28 & 2.43 & 2.33 & 2.29 \\
\hline
\end{tabular}

Data source:Uncomtrade database( https://comtrade.un.org/db/).

\section{Dependence analysis of China's energy imports}

Measurement method of dependence on international energy market.Take China's oil imports from $\mathrm{A}$ as an example. The two countries are mutually trading partners, so they are interdependent and cannot do without each other. However, if China's oil imports from A account for a greater proportion of its total oil imports, then China's dependence on A's oil exports is higher; on the contrary, if China's expenditure on oil imports from A accounts for a larger part in A's total income from its exports, then A is more dependent on China's oil consumption market. Therefore, the proportion of China's oil imports from A in its total and the proportion of China's expenditure on oil imports from A in A's total foreign exchange earnings should be comprehensively analyzed. In addition, if A's oil exports account for a lower proportion of the world's total, then China can easily import oil from other countries, therefore, the greater the proportion of A's oil exports in the world's total, the higher the dependence of China on A's oil exports. In this way, this article estimated the dependence of China's oil imports on A's oil exports according to the following steps ${ }^{[2][3]}$.

First, the weight of China's oil imports from A divided the total weight of China's oil imports, and the greater result indicated the higher dependence of China on A's oil exports. Second, the amount of money paid by China on the oil imports from A divided A's total export income, and the greater result indicated the higher dependence of A on China's oil consumption market. Third, the result of the first step divided that of the second step, and the greater value indicated that China's oil imports were dependent on A's oil exports and A's oil exports were not dependent on China's oil consumption. At this point, China's oil imports had higher dependence on A's oil exports. Finally, the total amount of A's oil exports divided the total amount of oil exports in the world, and then the result multiplied that of the third step. By combining A's importance in the international oil market, China's dependence on A's oil exports was comprehensively analyzed.

In the same way, China's dependence on other major oil exporters could be calculated, and its dependent coefficient of other energy could also be obtained. Although geopolitical factors were not considered, the dependent coefficient calculated by the above four steps, to a certain extent, can be used to assess the dependence of China's energy imports on a major exporter. For example, due to western economic sanctions against Iran, the dependence of Iran's oil exports on oil-consuming countries such as China and India increased, which reduced China's dependence on Iran's oil. As Russia's exports are richer and less dependent on oil exports, China's dependence on Russia's oil is relatively higher than Iran's. This is why in recent years the price of China's oil imported from Iran is lower than that from Russia and other Middle Eastern countries. For example, in 2013, the average price of China's imports of crude oil from Iran was 566 US dollars per ton, while that from Russia and Saudi Arabia was 582 and 572 US dollars per ton. Of course, the size of the dependent coefficient only shows the relative size of China's dependence on different sources of energy imports, and it is difficult to make judgment on its absolute value.

Empirical analysis of China's energy dependence on main sources of imports. The analysis of the dependency of China's oil imports by means of the calculated result in Table 5 showed that, from the perspective of trade, Vietnam, Indonesia, Kazakhstan and the United Arab Emirates are least 
dependent on China's oil imports, while Saudi Arabia and Russia are most dependent on China's oil imports.

Table 5 China's oil dependence on main sources of imports

\begin{tabular}{c|c|c|c|c|c|c|c|c|c|c}
\hline country & 2006 & 2007 & 2008 & 2009 & 2010 & 2011 & 2012 & 2013 & 2014 & 2015 \\
\hline Brize & 0 & 0.017 & 0.019 & 0.02 & 0.026 & 0.027 & 0.027 & 0.028 & 0.029 & 0.027 \\
\hline Indonisia & 0.018 & 0.03 & 0.023 & 0.015 & 0.016 & 0.013 & 0.014 & 0.014 & 0.016 & 0.021 \\
\hline Iran & 0.028 & 0.109 & 0.102 & 0.057 & - & - & 0.028 & 0.016 & 0.011 & 0.013 \\
\hline Kazakhstan & 0.058 & 0.016 & 0.016 & 0.016 & 0.011 & 0.013 & 0.012 & 0.013 & 0.012 & 0.013 \\
\hline Oman & 0.013 & 0.009 & 0.009 & 0.006 & 0.046 & 0.047 & 0.05 & 0.047 & 0.031 & 0.028 \\
\hline Russia & 0.165 & 0.695 & 0.646 & 0.512 & 0.994 & 0.035 & 0.134 & 0.114 & 0.121 & 0.125 \\
\hline Saudi Arabia & 0.502 & 0.825 & 0.87 & 0.612 & 0.217 & - & 0.355 & 0.528 & 0.532 & 0.543 \\
\hline UAE & 0.196 & 0.16 & 0.153 & 0.132 & 0.02 & 0.019 & 0.026 & 0.02 & 0.021 & 0.024 \\
\hline Viet Nam & 0.01 & 0.01 & 0.008 & 0.006 & 0.004 & 0.003 & 0.003 & 0.005 & 0.004 & 0.005 \\
\hline Data SOurce:
\end{tabular}

Data source:Uncomtrade database( https://comtrade.un.org/db/).

As can be found from the analysis of the stability of coal import markets (Table 6), Kyrgyzstan, New Zealand and Malaysia are the most reliable sources of China's coal imports, while the United States, Australia and Russia are not reliable.

Table 6 China's coal dependence on main sources of imports

\begin{tabular}{c|c|c|c|c|c|c|c|c|c|c}
\hline country & 2006 & 2007 & 2008 & 2009 & 2010 & 2011 & 2012 & 2013 & 2014 & 2015 \\
\hline Australia & 51.87 & 19.9 & 15.46 & 15.09 & 9.91 & 12.83 & 4.3 & 5.6 & 5.72 & 6.12 \\
\hline Canada & 22.31 & 8.01 & 7.08 & 4.21 & 3.12 & 2.36 & 1.05 & 1.12 & 1.34 & 1.52 \\
\hline Indonisia & 15.12 & 8.2 & 7.41 & 7.24 & 5.43 & 4.4 & 2.41 & 2.94 & 3.31 & 3.22 \\
\hline Kyrghyzstan & 0 & 0 & 0 & 0 & 0 & 0 & 0 & 0 & 0 & 0 \\
\hline Malaysia & 0 & 0.005 & - & 0 & 0.004 & 0.003 & 0.001 & 0 & 0.001 & 0 \\
\hline Mongolia & 0.002 & 0.003 & 0.002 & 0.002 & 0.003 & - & - & - & 0.003 & 0.002 \\
\hline New Zealand & 0.094 & 0.051 & 0.029 & 0.02 & 0.008 & 0 & 0 & 0 & 0 & 0 \\
\hline Russia & 27.95 & 15.1 & 11.9 & 12.78 & 9.26 & 4.74 & 2.58 & 3.12 & 3.24 & 3.45 \\
\hline US. & 90.66 & 2.01 & 6.13 & 4.87 & 5.3 & 11.52 & 4.33 & 5.28 & 6.12 & 6.55 \\
\hline Viet Nam & 0.78 & 0.55 & 0.5 & 0.6 & 0.48 & 0.34 & - & 0.56 & 0.49 & 0.57 \\
\hline Data sour & 0.96 & & 0 \\
\hline
\end{tabular}

Data source:Uncomtrade database( https://comtrade.un.org/db/).

As can be seen from Table 7, if only trade factors are considered, Kuwait, Iran, Nigeria and the United Arab Emirates are the safest sources of China's natural gas imports, while Australia and Malaysia are relatively unsafe. 
Table 7 China's nature gas dependence on main sources of imports

\begin{tabular}{c|c|c|c|c|c|c|c|c|c|c}
\hline country & 2006 & 2007 & 2008 & 2009 & 2010 & 2011 & 2012 & 2013 & 2014 & 2015 \\
\hline Algeria & 1.18 & 1.07 & - & - & 1.74 & 1.33 & 1.1 & 1.01 & 1.19 & 1.14 \\
\hline Australia & 0.73 & 0.64 & 0.78 & 0.8 & 1.63 & 4.83 & 2.86 & 3.12 & 3.18 & 3.21 \\
\hline Iran & 0.06 & 0.06 & 0.09 & 0.13 & - & - & - & - & 0.11 & 0.09 \\
\hline Kuwait & - & - & - & 0.01 & 0.14 & 0.16 & 0.08 & 0.09 & 0.08 & 0.13 \\
\hline Malaysia & 2.04 & 2.24 & 1.99 & - & 1.92 & 1.63 & 2.39 & 2.19 & 2.32 & 2.41 \\
\hline Nigeria & - & - & - & - & 0.03 & 0.01 & 0.18 & 0.1 & 0.08 & 0.15 \\
\hline Qatar & - & - & 0.48 & 7.5 & 0.71 & 0.93 & - & - & 0.89 & 0.85 \\
\hline Saudi Arabia & 1.89 & 2.05 & 2.26 & 3.17 & 2.31 & 2.44 & 1.08 & 1.38 & 1.42 & 1.46 \\
\hline AUE & 0.16 & 0.16 & 0.36 & - & - & 0 & - & 0.08 & 0.17 & 0.21 \\
\hline
\end{tabular}

Data source:Uncomtrade database( https://comtrade.un.org/db/).

\section{Conclusions}

China's oil, coal and natural gas import market structures are concentrated. In contrast, coal imports are the most concentrated, while oil imports are more dispersed. Fortunately, oil has a greater impact on China's economic security, and although there is a greater risk of coal from the perspective of import trade, because China's coal reserves are rich, the proportion of imports is low; therefore, the current coal import pattern will not pose a threat to China's coal supply security. In contrast, due to the rapid growth of China's economy in recent years, natural gas imports grow fast, and the import market structure is more concentrated, so the security of natural gas supply is worthy of attention. On the whole, China's energy import market structure is more concentrated and different sources of imports are different in the price, which is not conducive to long-term energy security. In the last decade, the structural improvement is also limited. If the export space of international energy market can be fully used and the sources of imports can be further diversified, the security of China's energy supply and its status in the trade negotiations with some energy export countries can be effectively improved to reduce energy import prices and improve energy trade terms.

\section{References}

[1] Hao Wei: Finance \& Trade Economics Vol. 5 (2007), p. 11(In Chinese)

[2] Friedman George and Lebard Meredith: The Coming War with Japan. st. Martin's Publising, NY (1991), in press,P.172

[3] Longbo Fu,Funing Zhong,Zhigang Xu: Management World Vol. 3 (2001), p. 135(In Chinese) 